\title{
Numerical simulations of the impacts of land-cover change in the intertidal zone on local meteorology in western Korea
}

\author{
Hye Yeon An ${ }^{1}$, Ju-Hee Jeong ${ }^{2, *}$, Yoon-Hee Kang ${ }^{3}$, Hyunsu Kim ${ }^{4}$, Yoo-Keun Kim ${ }^{2}$, and Zang-Ho Shon ${ }^{5}$ \\ ${ }^{1}$ Division of Earth Environmental System, Pusan National University, Busan, Republic of Korea \\ ${ }^{2}$ The Institute of Environmental Studies, Pusan National University, Busan, Republic of Korea \\ ${ }^{3}$ Environmental Research Institute, Ajou University, Suwon, Republic of Korea \\ ${ }^{4}$ National Electric Control Center, Korea Power Exchange, Naju, Republic of Korea \\ ${ }^{5}$ Department of Environmental Engineering, Dong-Eui University, Busan, Republic of Korea
}

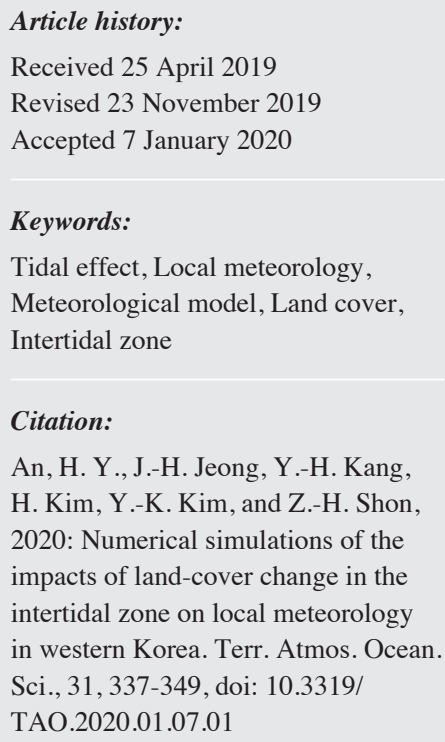

Citation:

An, H. Y., J.-H. Jeong, Y.-H. Kang, H. Kim, Y.-K. Kim, and Z.-H. Shon, 2020: Numerical simulations of the impacts of land-cover change in the intertidal zone on local meteorology in western Korea. Terr. Atmos. Ocean. Sci., 31, 337-349, doi: $10.3319 /$ TAO.2020.01.07.01

\begin{abstract}
The impact of land cover change in the intertidal zone ( $8.2 \%$ of the total surface area) on meteorology was evaluated using the Weather Research and Forecasting (WRF) model during summer (19 - 21 August 2016) and winter (9 - 11 February 2016). The heat flux change in the intertidal zone due to the tidal effects was greater in summer than in winter. During high tide in summer, the heat flux increased before sunrise and after sunset and decreased after sunrise and before sunset. During low tide, the overall heat flux decreased. In winter, a notable feature was the positive sensible heat flux before sunrise and after sunset during high tide due to a high sea surface temperature. The horizontal and vertical impacts of the tidal phenomena on the coastal meteorology were more pronounced during high tide than during low tide. The temperature decreased in inland areas and intertidal zone in summer afternoons, and increased at sea in winter mornings. The water vapor mixing ratio during the summer period increased in inland from the coastline. The wind speed during high tide at sea increased overall in summer and winter due to the decreased roughness length. During the summer period, the westerly wind speed significantly increased in the lower atmosphere (within $0.4 \mathrm{~km}$ ) over coastal areas, and the easterly wind speed increased at the heights (approximately $1 \mathrm{~km}$ ) of the return current of the sea breeze. These horizontal and vertical variations in sea breeze circulation induced horizontal meteorological differences in the Seoul metropolitan areas (approximately $30 \mathrm{~km}$ away from the coastline) and vertical differences within the planetary boundary layer (approximately $1.5 \mathrm{~km}$ altitude).
\end{abstract}

\section{INTRODUCTION}

The intertidal zone is defined as the area between the shoreline at high tide and the shoreline at low tide. It is alternately exposed and inundated by low and high tides, respectively (Harrison and Phizacklea 1985). The Korean tidal wetland, with a total area of $2487 \mathrm{~km}^{2}$, is one of the largest tidal flats in the world (Scott et al. 2014). The intertidal zone of Gyeonggi Bay, which is located on the West Sea of the Korean Peninsula, accounts for $35.2 \%$ of the total Korean tidal wetlands, and the tidal range is very large (up to $10 \mathrm{~m}$ ). The intertidal zone of Gyeonggi Bay plays an important role

\footnotetext{
* Corresponding author

E-mail:jeongjuhee@pusan.ac.kr
}

in sustaining the ecological health of the region (Hong et al. 2010; Ryu et al. 2016); it also affects coastal meteorology and air pollution in the adjacent urban region, namely the Seoul metropolitan area. Coastal meteorology around the intertidal zone has become a larger research focus within the study of the formation of sea fog due to tides (Tokinaga and Xie 2009; Lathlean et al. 2011; Raubenheimer et al. 2013; Heo et al. 2014; Lee et al. 2016).

The intertidal zone of Gyeonggi Bay experiences a change in land cover twice a day, corresponding to the low and high tides. These semidiurnal land cover changes modify the physical surface properties, including surface roughness, albedo, and heat capacity, of the intertidal zones, and 
lead to regional meteorological change in the intertidal zone and its adjacent coastal areas (Piccolo et al. 1993; Ahrens 2009). Piccolo et al. (1993) analyzed changes in the air temperature characteristics of the Starrs Point tidal flat sediments from tidal inundation and examined the influences of these changes on the air-water-soil interaction processes. Ahrens (2009) demonstrated that the significant changes in the surface fluxes between the inundation and exposure periods could influence the development and growth of convective storms with short lifetimes.

In order to understand the impact of land cover change on coastal meteorology in the intertidal zone, it is necessary to execute a meteorological model with consideration for the tidal effect. However, only a few meteorological modeling studies on the tidal effect in intertidal zones have been conducted. Lee et al. (2016) developed a parameterization of tidal effects for use in the Noah land-surface model and validated the land-surface model. They simulated changes in the surface energy flux, soil temperature, and roughness length due to tidal effects. Most previous studies have tended to research micrometeorology in the intertidal zone through observations (Harrison and Phizacklea 1985; Kim et al. 2007; Onken et al. 2007).

The main aim of this study was to assess the impact of land cover change in the intertidal zone on local meteorology using a meteorological model. In section 2, detailed descriptions of the meteorological model, data, and experimental design for this study are presented. In section 3 , the evaluation of the direct impact of land cover changes in the intertidal zone on meteorological variables [e.g., air temperature $(\mathrm{T})$, water vapor mixing ratio $(\mathrm{Q})$, and wind speed (WS)], as well as the horizontal and vertical variations in local meteorology around the intertidal zone, using numerical simulation data, is presented.

\section{MATERIALS AND METHODS}

\subsection{WRF Model Simulation and Input Data}

The meteorological model used in this study was the Weather Research and Forecasting (WRF) model version 3.8, a non-hydrostatic model designed for numerical weather prediction on scales ranging from meters to thousands of kilometers, developed by the National Center for Atmospheric Research (NCAR) (Skamarock et al. 2008). The computational domain in the WRF model consists of $43 \mathrm{sig}$ ma vertical layers, densely composed by 11 layers from the surface to $1 \mathrm{~km}$ height (sigma level $=0.996,0.990,0.980$, $0.970,0.960,0.950,0.940,0.930,0.920,0.910,0.895$, and the lowest half sigma level is about $17.3 \mathrm{~m}$ ), and four nested domains: $27-\mathrm{km}$ grid (D1, $64 \times 58$ array), 9-km grid (D2, 70 $\times 76$ array), $3-\mathrm{km}$ grid (D3, $82 \times 82$ array), and $1-\mathrm{km}$ grid (D4, $115 \times 103$ array), which include both the Gyeonggi Bay and the Seoul metropolitan area, spanning $37.1-38.0^{\circ} \mathrm{N}$ and $125.9-127.3^{\circ} \mathrm{E}$ (Figs. 1a and b).

The land cover data were obtained from the Environmental Geographic Information Service (EGIS) of the Korea Ministry of Environment (KME) (http://egis.me.go.kr). In order to represent the intertidal zone, the land cover data of the tidal flats were obtained from the Ministry of Oceans and Fisheries (MOF) and the Korea Marine Environment Management Corporation (KOEM) (http://ecosea.go.kr). The gray area in Fig. 1b shows the tidal flats, which make up $8.2 \%$ of the total surface area.

The initial/lateral boundary conditions were generated from the National Center for Environmental Prediction (NCEP) Global Forecast System (GFS) data on $0.5^{\circ} \times 0.5^{\circ}$ grids every $6 \mathrm{~h}$, and the daily global sea surface temperature (SST) data were taken on a $0.5^{\circ}$ resolution. A detailed description of the physical options used for the simulation is

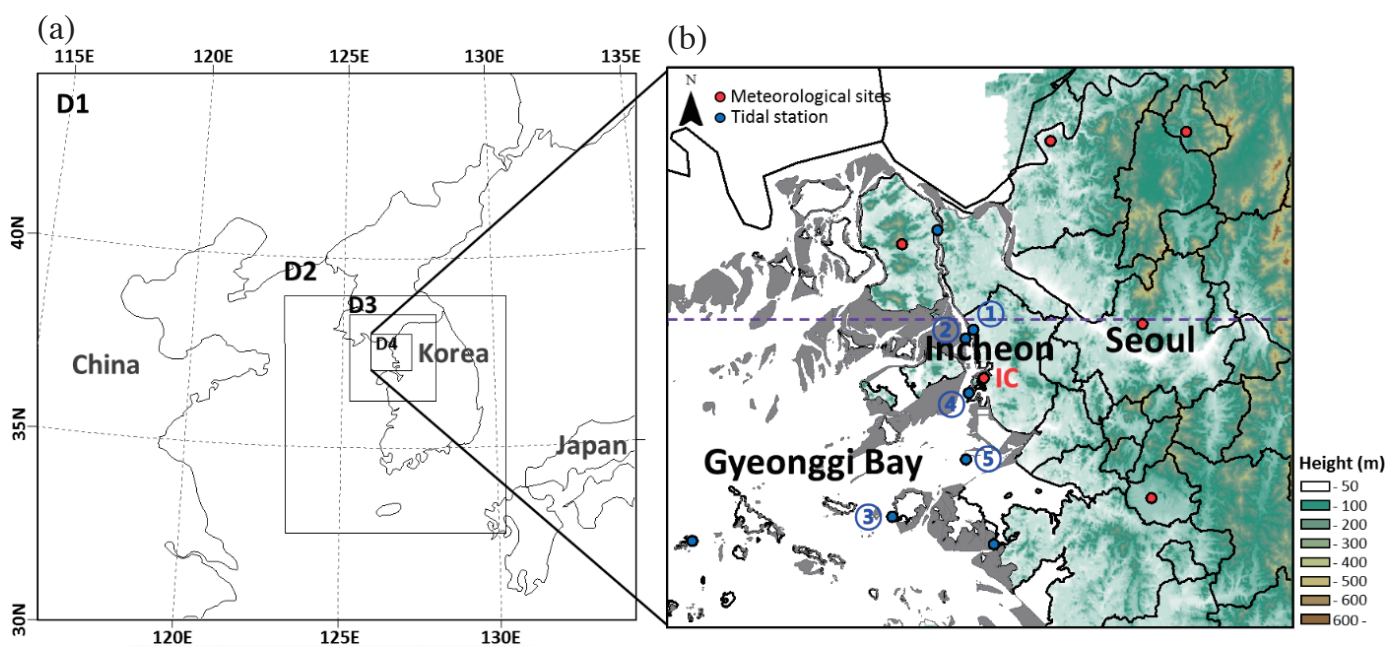

Fig. 1. Maps showing (a) the nested grid domains and (b) the enlarged study area. (a) shows the four nested grid domains (D1 - 4) for the WRF and (b) shows the topography and meteorological and tidal monitoring sites for D4. The red circles, blue circles, and the dotted line in (b) indicate the meteorological sites, tidal station, and vertical cross-section line, respectively. The gray areas in (b) represent the intertidal zone. 
given in Table 1. The schemes used are the schemes recommended by the KME to optimize meteorological modeling (http://capmos.nier.go.kr).

In order to identify the impact of the intertidal zone on local meteorology according to the season, the WRF simulations were conducted for $73 \mathrm{~h}$ in the summer period (from 00:00 UTC on 18 August to 00:00 UTC on 21 August 2016) and in the winter period (from 00:00 UTC on 8 February to 00:00 UTC on 11 February 2016), and a spin-up time of the first $18 \mathrm{~h}$ was used in the simulation to minimize the influence of insufficient initial conditions. Meteorological data (e.g., T, WS) from six automated synoptic observing systems (ASOS) and tide level data from five tidal stations (see Fig. 1b) were analyzed in order to select the appropriate modeling periods. The characteristics of the study periods are presented in Table 2. Incheon, a coastal area near the intertidal zone, had a daily average temperature of $29.3^{\circ} \mathrm{C}$ in summer and $2.7^{\circ} \mathrm{C}$ in winter, with a daily average wind speed below $4 \mathrm{~m} \mathrm{~s}^{-1}$. The observed tide levels at the five tidal stations during the summer and winter periods are shown in Fig. 2. We assumed that the high tide time was observed when the water depth was more than $6 \mathrm{~m}$, based on the Ramsar Convention's definition of coastal wetlands (Ramsar Convention Secretariat 2013). The high tide time consisted of about $6 \mathrm{~h}$ in the morning and $5 \mathrm{~h}$ in the afternoon for a given day. Low tide time was observed when the water depth was less than $3 \mathrm{~m}$, which consisted of about $4 \mathrm{~h}$ in the daytime and $4 \mathrm{~h}$ at nighttime, for a given day.

\subsection{Experimental Design}

Three sets of simulation experiments were conducted by constructing the different land cover in the intertidal zone: a simulation in which the land cover in the intertidal zone is tidal flats (WETLAND), a simulation in which the land cover in the intertidal zone is water bodies during high tide (HIGH), and a simulation in which the land cover in the intertidal zone is barren or sparsely vegetated during low tide (LOW). The WETLAND was a control experiment with HIGH representing the land cover at high tide and LOW representing the land cover at low tide. For quantitative verification of the experiment, some statistics related to the observed and simulated values of the meteorological variables [e.g., T, relative humidity (RH), and WS] were calculated, including the mean bias error (MBE), root mean square error (RMSE), and mean average gross error (MAGE) for WETLAND experiment. The MBE, RMSE, and MAGE between the surface observations provided by the Korea Meteorology Agency (KMA) and those made in WETLAND experiment were calculated at each observation grid point. Definitions of these metrics are as follows:

$\mathrm{MBE}=\frac{1}{N} \sum_{i=1}^{N}\left(F_{i}-O_{i}\right)$
$\mathrm{RMSE}=\sqrt{\frac{1}{N} \sum_{i=1}^{N}\left(F_{i}-O_{i}\right)^{2}}$

$\operatorname{MAGE}=\frac{1}{N} \sum_{i=1}^{N}\left|F_{i}-O_{i}\right|$

In Eqs. (1) - (3), $F_{i}$ is the number of simulations and $O_{i}$ represents the number of observations.

WRF defines several physical surface parameters that are used to define land cover characteristics. Table 3 provides the classification of land cover categories between the three experiments and the physical surface parameters used in the WRF model.

There are no physical surface parameters to characterize the land surface properties of tidal flats in the WRF model. Therefore, in this study, the physical surface parameters of tidal flats were newly defined by referring to other studies (Kim et al. 2007; Park et al. 2009; Han and Peng 2012), which was the observed surface albedo, roughness, and soil heat capacity of the tidal flat on the Korean Peninsula. The newly defined soil heat capacity, surface albedo, and roughness were $7.3 \times 10^{5} \mathrm{~J} \mathrm{~m}^{-2} \mathrm{~K}^{-1}$ larger, $1 \%$ larger, and $19.2 \mathrm{~cm}$ smaller than the soil heat capacity, surface albedo, and roughness of the herbaceous wetland category, respectively. Some other parameters, such as surface albedo, roughness, and soil heat capacity, were applied to the newly defined values and parameters such as moisture availability, emissivity, thermal inertia, and factor for albedo modification with snow were applied as values of the herbaceous wetland category.

\section{RESULTS AND DISCUSSION}

\subsection{Direct Impact of Land Cover Change in the Intertidal Zone}

As a means to evaluate the model's performance, we compared the observed and simulated meteorological variables (e.g., T, RH, and WS) for the WETLAND experiment, based on statistical analysis (MBE, RMSE, and MAGE) (Table 4). The statistical analysis was conducted at six meteorological monitoring sites. The mean MBE in T and RH was a negative value and a positive value in WS which can be considered underestimation and overestimation, respectively. The mean RMSE in T and RH was approximately $2{ }^{\circ} \mathrm{C}$ and $12 \%$, respectively, and that in WS was less than $2 \mathrm{~m} \mathrm{~s}^{-1}$. This implies that although there is some error in the WRF model, it successfully reproduces local meteorology. Based on the accuracy of the WRF model, the HIGH and LOW were analyzed.

In order to investigate the direct impact of land cover change caused by the tidal effect in the intertidal zone on the local climate during summer and winter, changes in the heat flux (e.g., sensible heat flux and latent heat flux) were 
Table 1. Details of the physical options used in the WRF model.

\begin{tabular}{c|c|c|c|c}
\hline Domains & D1 & D2 & D3 & D4 \\
\hline Microphysics & WSM3 & \multicolumn{3}{|c}{ WDM6 } \\
\hline Cumulus & KF & \\
\hline Radiation (long/short wave) & \multicolumn{3}{|c}{ RRTMG } \\
\hline Planetary boundary layer & \multicolumn{3}{|c}{ YSU } \\
\hline Land surface model & \multicolumn{3}{c}{ Noah } \\
\hline
\end{tabular}

Table 2. Study periods characterized by meteorological variables observed in meteorological site (IC) shown in Fig. 1.

\begin{tabular}{c|cccc}
\hline Study periods & $\begin{array}{c}\text { Daily average } \\
\text { temperature }\left({ }^{\circ} \mathbf{C}\right)\end{array}$ & $\begin{array}{c}\text { Daily average } \\
\text { wind speed }\left(\mathbf{m ~ s}^{-1}\right)\end{array}$ & Main wind direction & $\begin{array}{c}\text { Average cloud } \\
\text { amount }\left(\mathbf{1 0}^{-1}\right)\end{array}$ \\
\hline 03 LST 19 August 2016 to 04 LST 21 August 2016 & 29.3 & 2.3 & NNW & 7.0 \\
04 LST 9 February 2016 to 04 LST 11 February 2016 & 2.7 & 3.6 & NNW & 3.1 \\
\hline
\end{tabular}
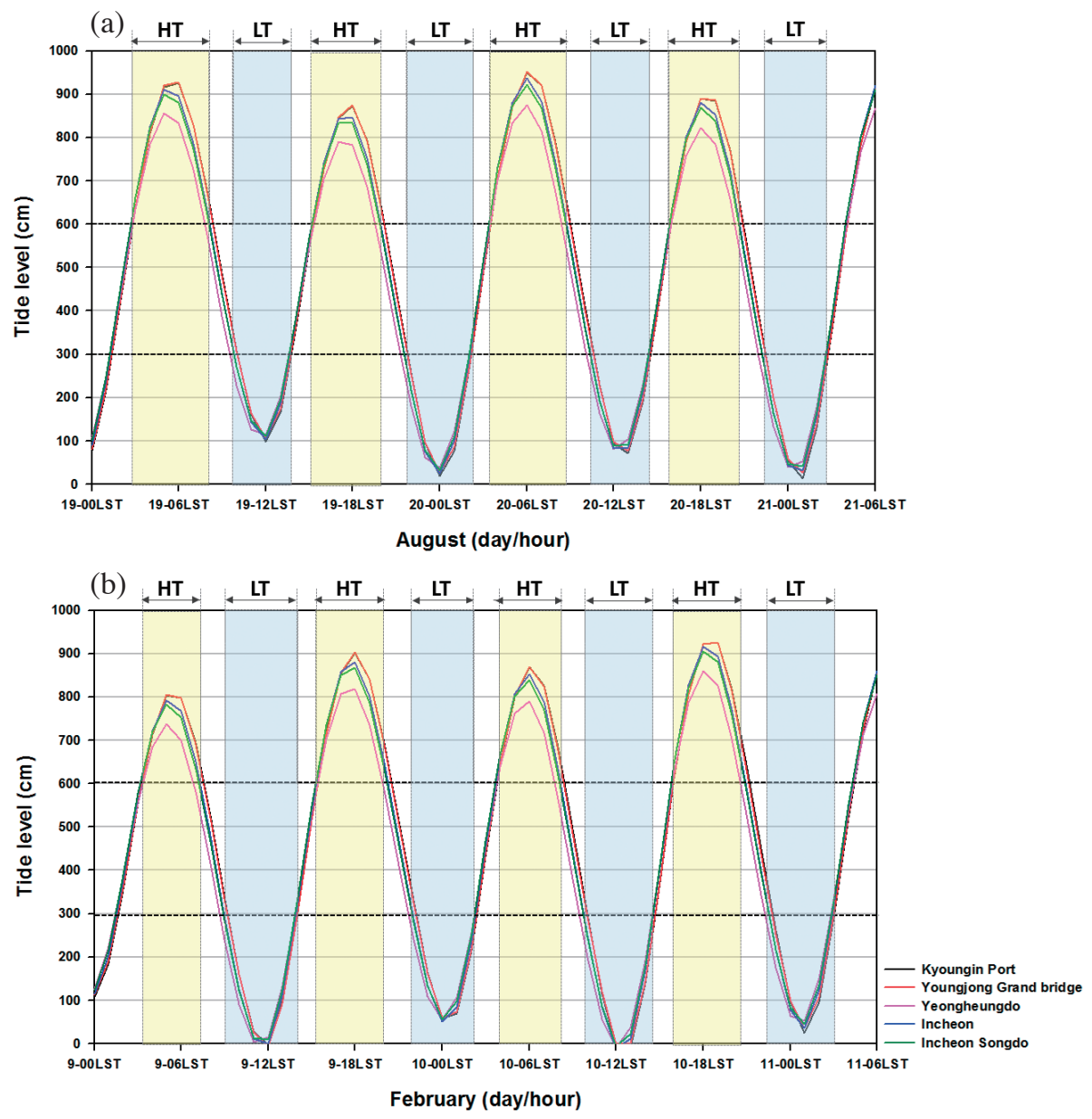

Fig. 2. Time series plots of the observed tide level at five tidal stations during the (a) summer and (b) winter periods of the year 2016 . The five tidal stations (1) - (5)) are shown in Fig. 1b. HT and LT refer to high tide and low tide, respectively. 
Table 3. Classifications of land cover categories of the gray area in Fig. $1 \mathrm{~b}$ for the three experiments and the representative values of the physical surface parameters used in the WRF model.

\begin{tabular}{c|ccc}
\hline Parameter & $\begin{array}{c}\text { WETLAND } \\
\text { (Land cover category: tidal flat) }\end{array}$ & $\begin{array}{c}\text { HIGH } \\
\text { (Land cover category: water } \\
\text { bodies) }\end{array}$ & $\begin{array}{c}\text { LOW } \\
\text { (Land cover category: barren or } \\
\text { sparsely vegetated) }\end{array}$ \\
\hline Albedo (\%) & 15 & 8 & 25 \\
Soil moisture availability $(\times 100 \%)$ & 0.6 & 1 & 0.02 \\
Surface emissivity (\%) & 0.95 & 0.98 & 0.9 \\
Roughness length $(\mathrm{cm})$ & 0.8 & 0.01 & 1 \\
Thermal inertia $\left(\mathrm{kJ} \mathrm{m}^{-2} \mathrm{~K}^{-1} \mathrm{~s}^{-1 / 2}\right)$ & 6 & 6 & 2 \\
Soil heat capacity $\left(\mathrm{J} \mathrm{m}^{-3} \mathrm{~K}^{-1}\right)$ & $36.5 \times 10^{5}$ & $9.0 \times 10^{25}$ & $12.0 \times 10^{5}$ \\
\hline
\end{tabular}

Table 4. Statistical evaluation of the observed and simulated meteorological variables (T, RH, and WS) for the WETLAND case

\begin{tabular}{c|cccc}
\hline Season & Statistics & T $\left({ }^{\circ} \mathbf{C}\right)$ & RH $(\%)$ & WS $\left(\mathbf{m ~ s}^{-1}\right)$ \\
\hline \multirow{4}{*}{ Summer } & MBE & -1.37 & -4.24 & 0.66 \\
& RMSE & 2.48 & 11.82 & 1.11 \\
& MAGE & 2.75 & 4.41 & 1.35 \\
\hline \multirow{3}{*}{ Winter } & MBE & -0.08 & -0.90 & 0.65 \\
& RMSE & 2.64 & 12.64 & 1.34 \\
& MAGE & 0.78 & 8.61 & 1.44 \\
\hline
\end{tabular}

analyzed along with meteorological variables (e.g., T, Q, and WS) on the intertidal zone grids. Figure 3 shows the diurnal variation in the intertidal zone area-averaged sensible and latent heat fluxes, and the difference between two experiments (WETLAND and HIGH at high tide, and WETLAND and LOW at low tide) on the intertidal zone grids. These analyses present the changes in energy exchange between the surface and atmosphere in accordance with the land cover change due to the tidal effect.

During the high tide of summer, the surface temperature of the intertidal zone in $\mathrm{HIGH}$ was higher by $1.7^{\circ} \mathrm{C}$ than that in WETLAND in the morning (0400 - 0700 LST), but significantly lower by $4.7^{\circ} \mathrm{C}$ than that in WETLAND in the afternoon (1600 - 1900 LST). During the high tide of winter, HIGH was higher by 5.2 and $1.2^{\circ} \mathrm{C}$ in the morning and afternoon, respectively, compared to WETLAND. During the low tide of summer, LOW was lower by 1.7 and $1.1^{\circ} \mathrm{C}$ than that in WETLAND during the daytime (1100 1300 LST) and nighttime (2300 - 0200 LST), respectively. During the low tide of winter, LOW was lower by $1.4^{\circ} \mathrm{C}$ compared to WETLAND during the daytime, and was similar to that in WETLAND during the nighttime. Overall, the surface temperature difference between HIGH and WETLAND was larger than that between LOW and WETLAND.

In summer, the sunrise time was 0553 LST and sunset time was 1923 LST. During the high tide, the sensible and latent heat fluxes in HIGH increased $7.8 \mathrm{~W} \mathrm{~m}^{-2}$ (up to
$16.5 \mathrm{~W} \mathrm{~m}^{-2}$ ) and $51.4 \mathrm{~W} \mathrm{~m}^{-2}$ (up to $90.0 \mathrm{~W} \mathrm{~m}^{-2}$ ) on average before sunrise and after sunset (0300 - 0600 LST and 1900 2000 LST), respectively. This was due to the relatively high SST compared to the surface temperature of the tidal flat. Those that decreased by $56.9 \mathrm{~W} \mathrm{~m}^{-2}$ (up to $112.8 \mathrm{~W} \mathrm{~m}^{-2}$ ) and $76.3 \mathrm{~W} \mathrm{~m}^{-2}$ (up to $156.5 \mathrm{~W} \mathrm{~m}^{-2}$ ) on average at $0700-0800$ LST and 1600 - 1800 LST, respectively, was due to the low SST. During low tide, the sensible heat flux in LOW slightly decreased by $22.0 \mathrm{~W} \mathrm{~m}^{-2}$ on average during the daytime, which was due to large albedo in LOW. The latent heat flux in LOW significantly decreased by $220.5 \mathrm{~W} \mathrm{~m}^{-2}$ on average during the daytime, which may be due to the relatively small soil heat capacity of LOW.

During high tide in winter, the sensible and latent heat fluxes in HIGH were slightly higher (sensible heat flux: mean $14.4 \mathrm{~W} \mathrm{~m}^{-2}$, maximum $68.0 \mathrm{~W} \mathrm{~m}^{-2}$, latent heat flux: mean $36.1 \mathrm{~W} \mathrm{~m}^{-2}$, maximum $76.0 \mathrm{~W} \mathrm{~m}^{-2}$ ) than those in WETLAND. A notable feature was the positive sensible heat flux during high tide before sunrise and after sunset in HIGH experiment. A positive heat flux was expected because the SST was higher than the air temperature at high tide before sunrise and after sunset. During low tide, sensible and latent heat fluxes in LOW were lower (mean 25.8 and $5.4 \mathrm{~W} \mathrm{~m}^{-2}$, respectively) than those in WETLAND. These significant changes in the sensible and latent heat fluxes in the intertidal zone are expected to affect meteorological variables such as temperature and water vapor. 
(a) Sensible heat flux

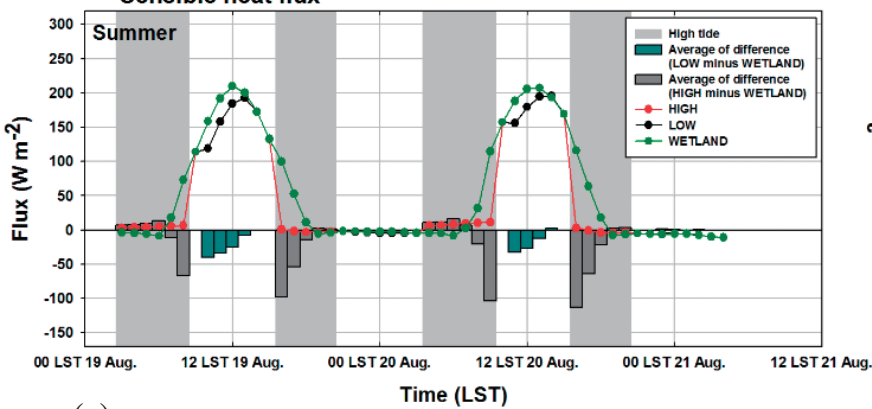

(c) Latent heat flux

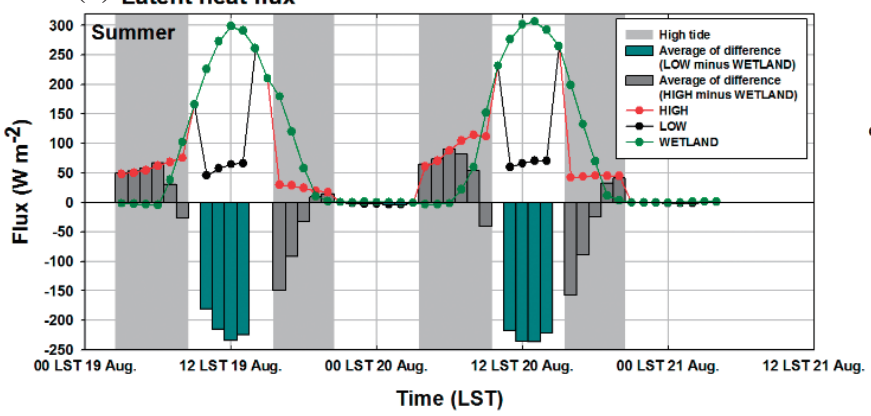

(b) Sensible heat flux

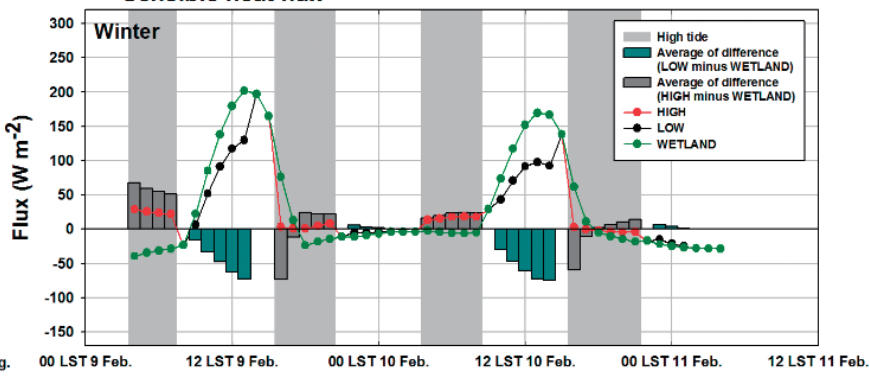

Time (LST)

(d) Latent heat flux

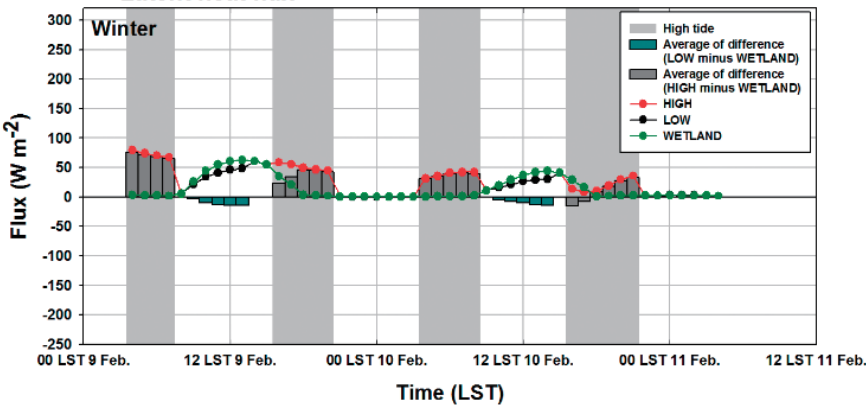

Fig. 3. Diurnal variation in area-averaged sensible and latent heat fluxes, and the difference between two experiments (HIGH and WETLAND, LOW and WETLAND) on the intertidal zone grid during the summer [(a) and (c)] and winter [(b) and (d)] periods.

Figure 4 shows the diurnal variations in the intertidal zone area-averaged $2 \mathrm{~m} \mathrm{~T}, 2 \mathrm{~m} \mathrm{Q}$, and $10 \mathrm{~m} \mathrm{WS}$. Overall, meteorological variations in the intertidal zone at high tide were more pronounced than that at low tide. During high tide in summer, the $\mathrm{T}$ in $\mathrm{HIGH}$ was higher $\left(2.1-2.4^{\circ} \mathrm{C}\right)$ than that in WETLAND in the early morning (0400 - 0600 LST) before sunrise. During the afternoon (1600 - 1900 LST), the T in HIGH was lower (up to $3.7^{\circ} \mathrm{C}$ ) than that in WETLAND. These results are likely to be caused by the increase and decrease in sensible heat flux in the morning and afternoon, respectively. During low tide, the T in LOW was lower (mean $0.3^{\circ} \mathrm{C}$, up to $1.1^{\circ} \mathrm{C}$ ) than that in WETLAND. The difference between LOW and WETLAND in $\mathrm{T}$ was much smaller than during high tide. In winter, SST was higher than land surface temperature before sunrise and after sunset. The $\mathrm{T}$ in $\mathrm{HIGH}$ was simulated to be higher than that in WETLAND for every period except $1600-1700$ LST, due to the relatively short daytime in winter. Overall, the Q considerably increased (spatial and temporal mean $\left.0.9 \mathrm{~g} \mathrm{~kg}^{-1}, 0.1-2.4 \mathrm{~g} \mathrm{~kg}^{-1}\right)$ in HIGH during high tide. The largest difference appeared during the afternoon in summer. Although the latent heat flux decreased, the increase of Q in HIGH experiment is likely caused by the supply of water vapor from water bodies at low PBL height, as the temperature decreases in the afternoon. During low tide in summer, the Q decreased $\left(0.8-1.4 \mathrm{~g} \mathrm{~kg}^{-1}\right)$ in LOW during the daytime due to a decrease in latent heat flux. The WS in HIGH slightly increased overall (spatial and temporal mean $0.5 \mathrm{~m} \mathrm{~s}^{-1}$ ), due to the decreased roughness length during high tide. The WS during low tide was not significantly different between LOW and WETLAND, due to the small difference between the two experiments in roughness. The horizontal and vertical meteorological impact, mainly during high tide, will be described in section 3.2 and 3.3, as the difference between LOW and WETLAND during low tide was very small.

\subsection{Horizontal Variation in Local Meteorology Around the Intertidal Zone}

The impacts of land cover change in the intertidal zone on the local meteorology of the Seoul metropolitan area were analyzed quantitatively during summer and winter. To identify the influence radius of the intertidal zone, the horizontal distributions of the time-averaged meteorological variables (e.g., T, Q, PBL heights, and WS) were analyzed during the high tides of the morning (0400 - 0700 LST) and afternoon (1600 - 1900 LST).

Figure 5 shows the mean difference (i.e., the effect of high tide) of the T, Q, PBL heights, and WS between both experiments (HIGH minus WETLAND) during the morning and afternoon of summer. In summer, the effect of high tide on $\mathrm{T}$ was varied according to the time period: as the intertidal zone was covered with water, $\mathrm{T}$ near the sea and intertidal zone, increased considerably (up to $2.5^{\circ} \mathrm{C}$ ) in the morning; however, it significantly decreased (up to $3.4^{\circ} \mathrm{C}$ ) at sea and the inland areas adjacent to the coastline in the afternoon. The increase in $\mathrm{T}$ in the morning was likely caused by 

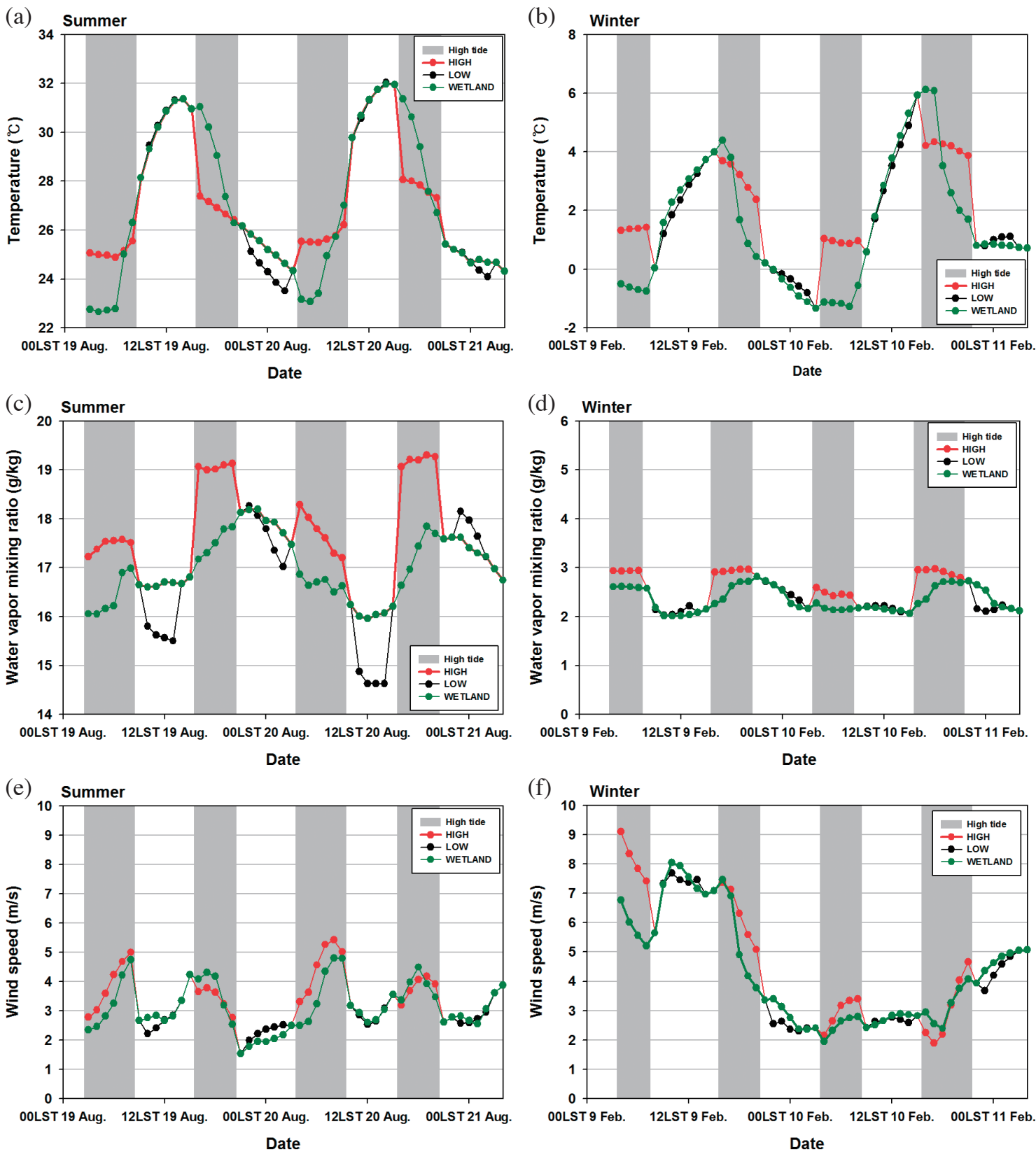

Fig. 4. Diurnal variations in the intertidal zone-averaged (a) (b) T, (c) (d) Q, and (e) (f) wind speed during the summer (a) (c) (e) and winter (b) (d) (f) periods. 
(a) Temperature

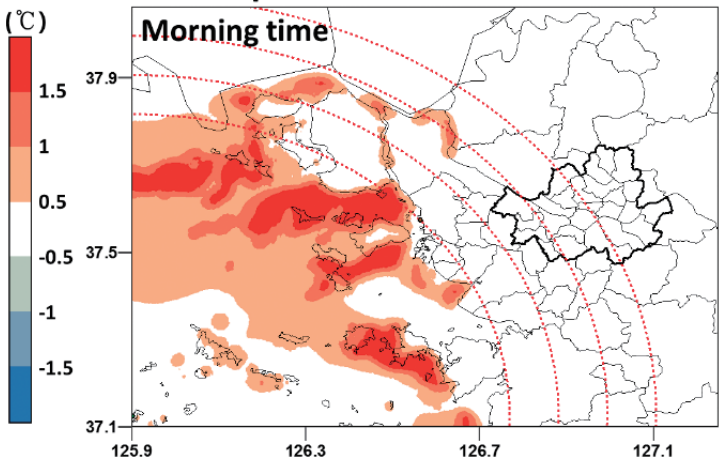

(c) Water vapor mixing ratio

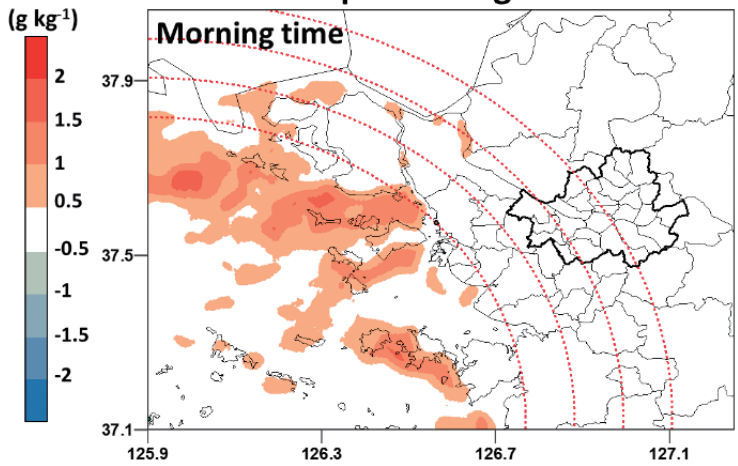

(e) PBL height

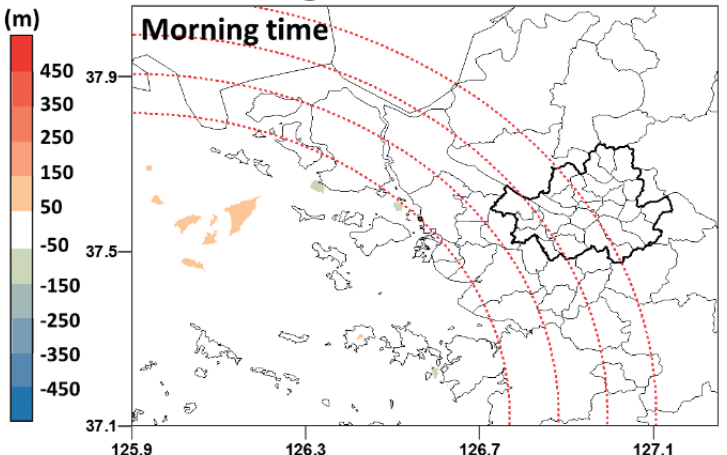

(g) Wind speed

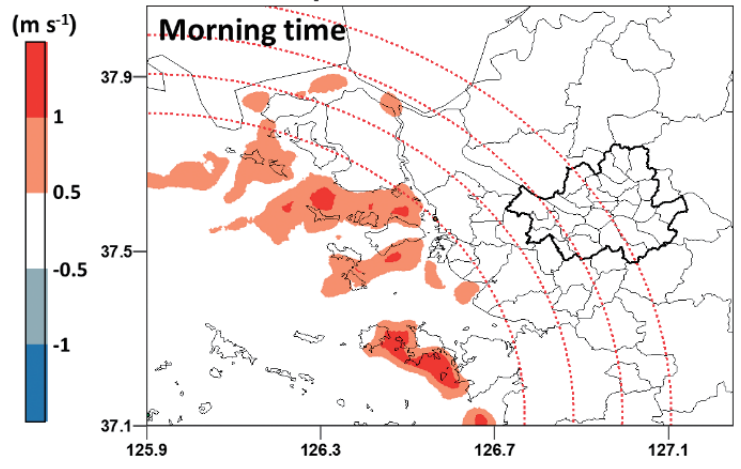

(b) Temperature

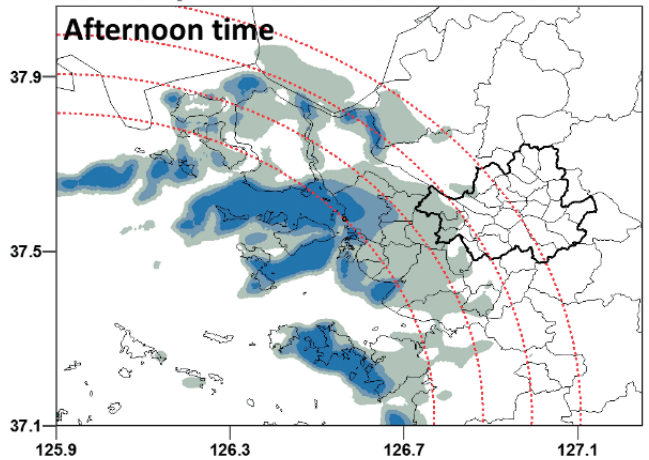

(d) Water vapor mixing ratio

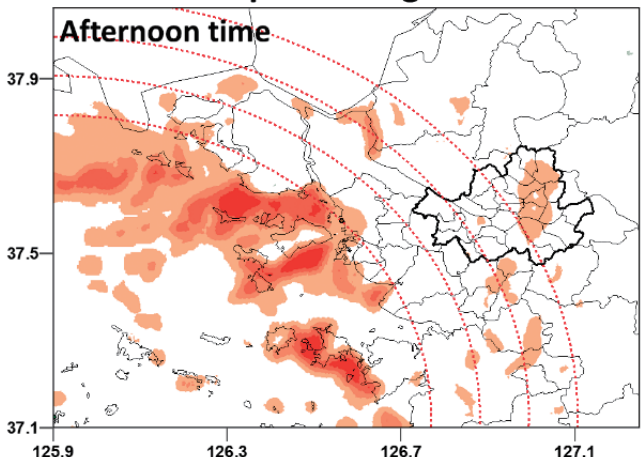

(f) PBL height

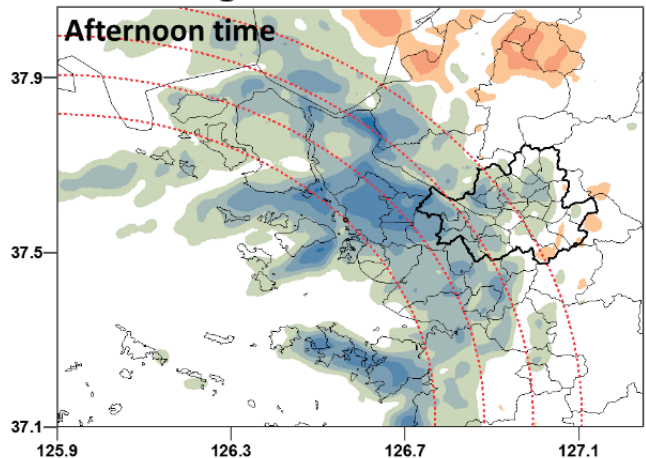

(h) Wind speed

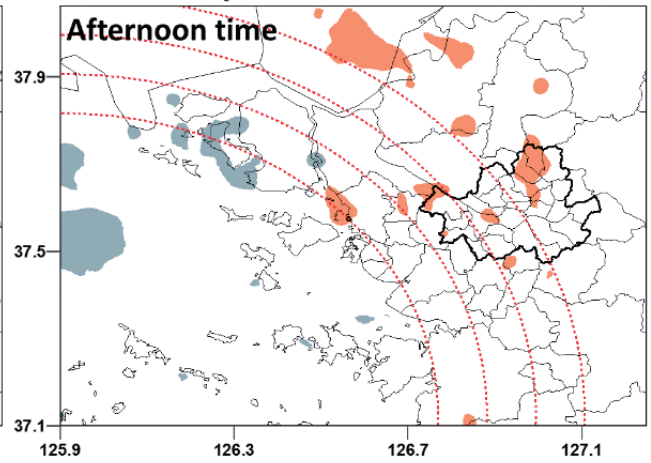

Fig. 5. Spatial distributions of the mean differences in (a) (b) T, (c) (d) Q, (e) (f) PBL height, and (g) (h) wind speed between HIGH and WETLAND (HIGH minus WETLAND) during the morning (0400 - 0700 LST) (a) (c) (e) (g) and afternoon (1600 - 1900 LST) (b) (d) (f) (h) of summer. The red dotted line indicates $10 \mathrm{~km}$ intervals from the intertidal zone. 
a relatively warmer surface temperature in the intertidal zone in HIGH $\left(26.2^{\circ} \mathrm{C}\right)$ than that in WETLAND $\left(24.5^{\circ} \mathrm{C}\right)$. Q increased overall, and this effect was particularly pronounced in the afternoon (up to $2.9 \mathrm{~g} \mathrm{~kg}^{-1}$ ). Also, Q in some inland areas increased slightly (less than $1 \mathrm{~g} \mathrm{~kg}^{-1}$ ) in the afternoon. The variations in $\mathrm{T}$ and $\mathrm{Q}$ in inland areas during the daytime were found when the sea breeze occurred. The PBL height significantly decreased $(124.7 \mathrm{~m})$ around inland areas from the coastline to approximately $30 \mathrm{~km}$ eastward during the afternoon because, in HIGH, the convective mixing was decreased with the decrease in sensible heat flux. The horizontal distribution of the PBL height differences was similar to that of $\mathrm{T}$ in the afternoon. WS in the morning increased up to $1.8 \mathrm{~m} \mathrm{~s}^{-1}$, mainly near the seas and intertidal zone, and that in the afternoon slightly increased up to $1.3 \mathrm{~m} \mathrm{~s}^{-1}$ in some areas inland.

In winter, with strong synoptic flows, variations in the local meteorology due to land cover changes in the intertidal zone were smaller than that in summer (Fig. 6). The difference in $\mathrm{T}$ (up to $3.2^{\circ} \mathrm{C}$ ) due to the effect of high tide in the morning was shown to have a similar distribution in winter to that in summer, but there was no difference in the afternoon. These minor differences may be caused by small differences between SST and surface temperature in the intertidal zone due to a relatively warm SST, while in summer, it was because $\mathrm{T}$ in the afternoon decreased due to a relatively low SST compared to the surface temperature in the intertidal zone during high tide. In the case of $\mathrm{Q}$, there was no significant difference, except for a slight increase $\left(0.5 \mathrm{~g} \mathrm{~kg}^{-1}\right)$ in some parts of the intertidal zone. The variation in the PBL height in the nearby sea and intertidal zone, was considerable. In the morning, the PBL height decreased $(60 \mathrm{~m})$ in the intertidal zone and increased $(29 \mathrm{~m})$ in the nearby sea. However, in the afternoon, PBL height decreased (71 m) in most regions. WS in the morning significantly increased (up to $2.7 \mathrm{~m} \mathrm{~s}^{-1}$ ) in the nearby sea and intertidal zone, due to a decrease in the roughness length induced by high tide. However, there was no difference in the afternoon. In the afternoon, the impact of roughness on the meteorology seems to be decreased by the occurrence of strong synoptic flow.

In summer, during the afternoon, when the effect of high tide is apparent inland of the Seoul metropolitan area, the intensity and range of the sea breeze were analyzed based on the variations in the $u$-component wind in the study area. Table 5 presents the area-averaged values and area percentages of the positive $u$ - (westerly wind) and negative $u$-components (easterly wind) for the intertidal zone and the whole domain area, respectively. The grids with a positive $u$-component in both the intertidal zone and the whole domain area increased (by averages of 2.6 and $2.8 \%$, respectively) with the effect of high tide. These results imply that the range of the sea breeze, due to the effect of high tides, was increased in the intertidal zone and over the whole domain area.

\subsection{Vertical Distribution of Local Meteorology in the Boundary Layer}

To identify the quantitative vertical impacts of land cover changes in the intertidal zone on the meteorology, vertical cross-sections were taken along the line shown in Fig. 1b. The vertical cross-sections are presented in Fig. 7. At 0400 LST on 20 August 2016 (morning) and 1600 LST on 20 August 2016 (afternoon) the effect of high tide was large during the summer period. According to vertical cross-section analysis, $\mathrm{T}$ and $\mathrm{Q}$ increased (up to $1.7^{\circ} \mathrm{C}$ and $1.2 \mathrm{~g} \mathrm{~kg}^{-1}$, respectively) in the morning when there was a lower atmosphere (within $0.1 \mathrm{~km}$ ) of the nearby sea and intertidal zone. There was a slight change in the wind speed above the intertidal zone, but no change in wind direction. In the afternoon, $\mathrm{T}$ and $\mathrm{Q}$ significantly decreased (up to $4.2^{\circ} \mathrm{C}$ ) and increased (up to $3.7 \mathrm{~g} \mathrm{~kg}^{-1}$ ), respectively, in the lower atmosphere (within $0.4 \mathrm{~km}$ ) on the adjacent land and intertidal zone. However, in the atmosphere layer (approximately 0.6 $-0.8 \mathrm{~km}$ ) on the intertidal zone and the upper atmosphere (approximately $1.5-2.5 \mathrm{~km}$ ) on the surrounding land, $\mathrm{T}$ and Q slightly increased (up to $\left.1.6^{\circ} \mathrm{C}\right)$ and decreased $\left(2.2 \mathrm{~g} \mathrm{~kg}^{-1}\right)$, respectively. In the case of the wind field, WS significantly increased (up to $5.4 \mathrm{~m} \mathrm{~s}^{-1}$ ) in the lower atmosphere (within $0.4 \mathrm{~km}$ ) and atmosphere layer (approximately $0.8-1.8 \mathrm{~km}$ ) on the adjacent land (until approximately $16.7 \mathrm{~km}$ from the intertidal zone) and intertidal zone. It is considered that WS in the lower atmosphere increased due to a greater land-sea contrast caused by high tide, and, thus, the sea breeze penetrated further inland (to approximately $7 \mathrm{~km}$ ) in the Seoul metropolitan area. In addition, the easterly WS increased at the heights (approximately $1 \mathrm{~km}$ ) of the return current of the sea breeze as the sea breeze changes on the surface affected the upper atmosphere. Thus, the variations in $\mathrm{T}$ and $\mathrm{Q}$ in the atmosphere layer (approximately $0.6-1.8 \mathrm{~km}$ ) were influenced by the intensification of sea breeze circulation.

\section{SUMMARY AND CONCLUSIONS}

The impact of land cover change, induced by tidal effect, in the intertidal zone of the West Sea on coastal meteorology was evaluated during summer and winter using the WRF model. During high tide of summer, the sensible and latent heat fluxes increased (mean 7.8 and $51.4 \mathrm{~W} \mathrm{~m}^{-2}$, respectively) in the absence of solar radiation (before sunrise and after sunset) and decreased (mean 56.9 and $76.3 \mathrm{~W} \mathrm{~m}^{-2}$ ) in the presence of solar radiation. Whereas, during the winter period, the fluxes generally increased (approximately 5.9 and $14.7 \mathrm{~W} \mathrm{~m}^{-2}$ ), but the differences were smaller than those during the summer period. During low tide, the sensible and latent heat fluxes in summer decreased (mean 10.6 and $104.9 \mathrm{~W} \mathrm{~m}^{-2}$, respectively) and those in winter also decreased (mean 25.8 and $5.4 \mathrm{~W} \mathrm{~m}^{-2}$, respectively). 
(a) Temperature

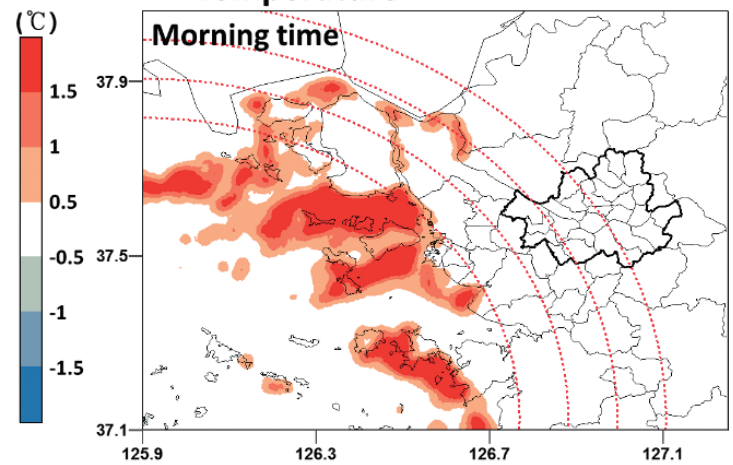

(c) Water vapor mixing ratio

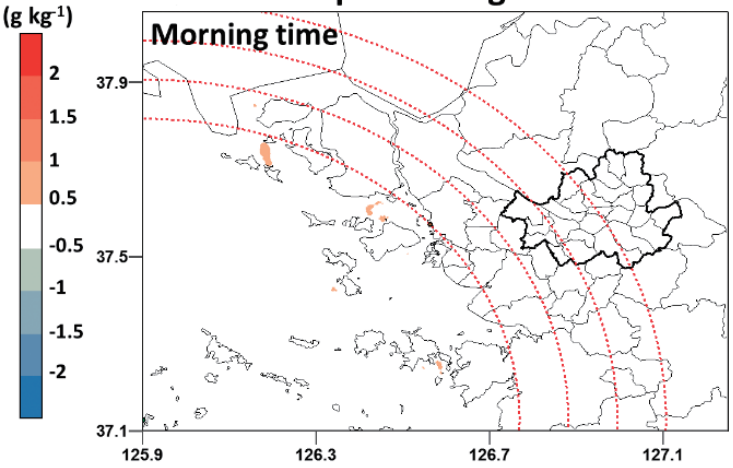

(e) PBL height

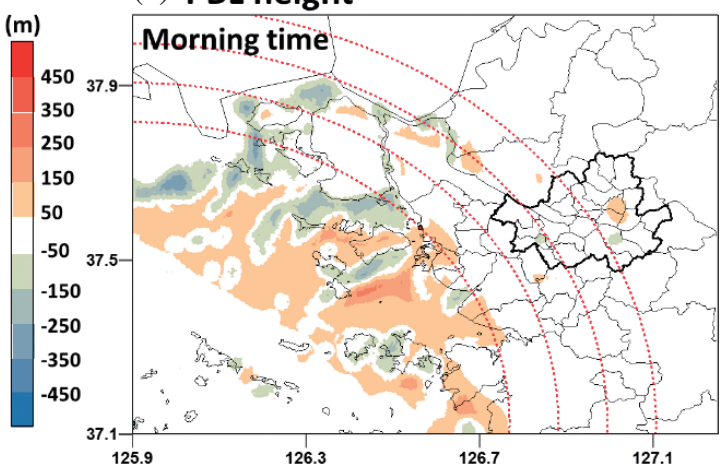

(g) Wind speed

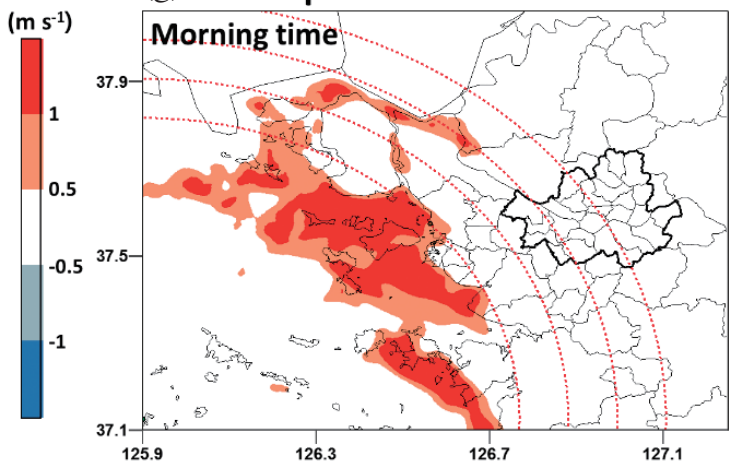

Fig. 6. Same as Fig. 5 but for winter.

\section{(b) Temperature}

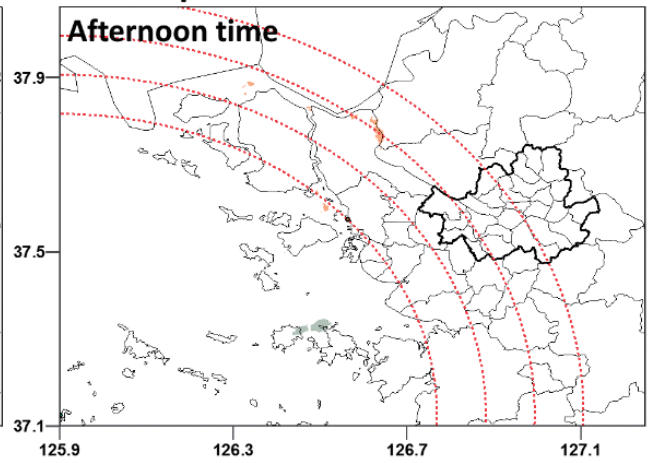

(d) Water vapor mixing ratio

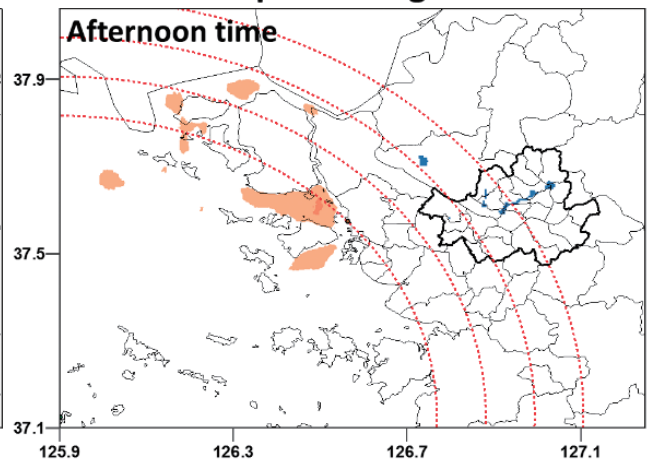

(f) PBL height

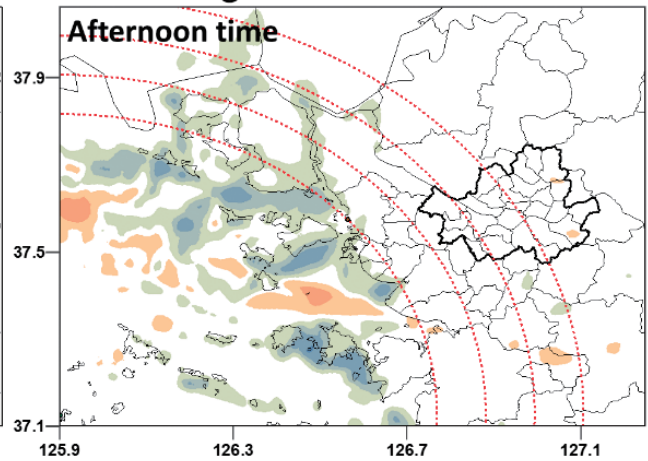

(h) Wind speed

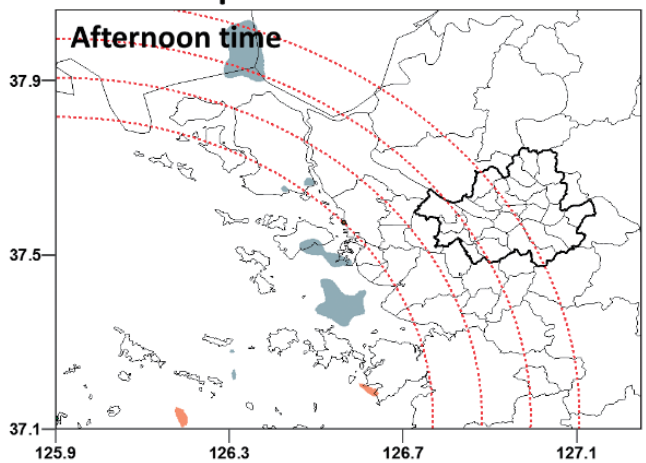


Table 5. Average of $\mathrm{u}$-component for westerly wind $(\mathrm{u}>0)$ and easterly wind $(\mathrm{u}<$ $0)$ at 1600 - 1900 LST for the intertidal zone and the whole area, respectively. The value in the parenthesis is percentage of area with westerly and easterly wind.

\begin{tabular}{c|c|cc|cc}
\hline \multicolumn{2}{c|}{} & \multicolumn{2}{c|}{ Intertidal zone area } & \multicolumn{2}{c}{ Whole domain area } \\
\cline { 3 - 6 } \multicolumn{2}{c|}{} & HIGH & WETLAND & HIGH & WETLAND \\
\hline \multirow{2}{*}{1600 LST } & $\mathrm{u}>0$ & $2.2(85.7)$ & $2.2(82.3)$ & $2.3(84.4)$ & $2.4(80.5)$ \\
& $\mathrm{u}<0$ & $-0.8(14.3)$ & $-0.8(17.7)$ & $-0.8(15.6)$ & $-0.9(19.5)$ \\
\hline \multirow{2}{*}{1700 LST } & $\mathrm{u}>0$ & $2.7(87.8)$ & $2.7(85.9)$ & $2.8(86.5)$ & $2.8(84.4)$ \\
& $\mathrm{u}<0$ & $-0.9(12.2)$ & $-0.9(14.1)$ & $-1.0(13.5)$ & $-0.9(15.6)$ \\
\hline \multirow{3}{*}{1800 LST } & $\mathrm{u}>0$ & $2.8(89.6)$ & $2.9(88.1)$ & $3.0(87.7)$ & $3.1(85.6)$ \\
& $\mathrm{u}<0$ & $-0.9(10.4)$ & $-0.9(11.9)$ & $-1.0(12.3)$ & $-0.9(14.4)$ \\
\hline \multirow{2}{*}{1900 LST } & $\mathrm{u}>0$ & $2.4(94.7)$ & $2.5(91.3)$ & $2.6(89.6)$ & $2.8(86.5)$ \\
& $\mathrm{u}<0$ & $-0.8(5.3)$ & $-0.9(8.7)$ & $-0.9(10.4)$ & $-0.9(13.5)$ \\
\hline
\end{tabular}

(a) WETLAND (04 LST 20 Aug., 2016)

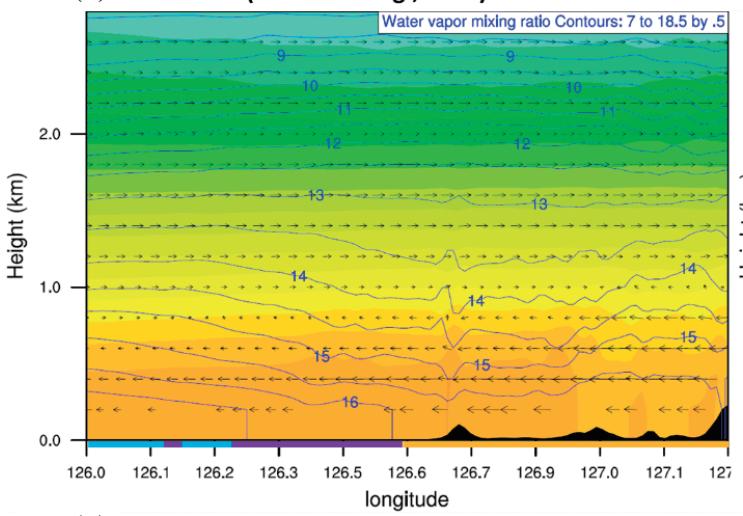

(c) WETLAND (16 LST 20 Aug., 2016)

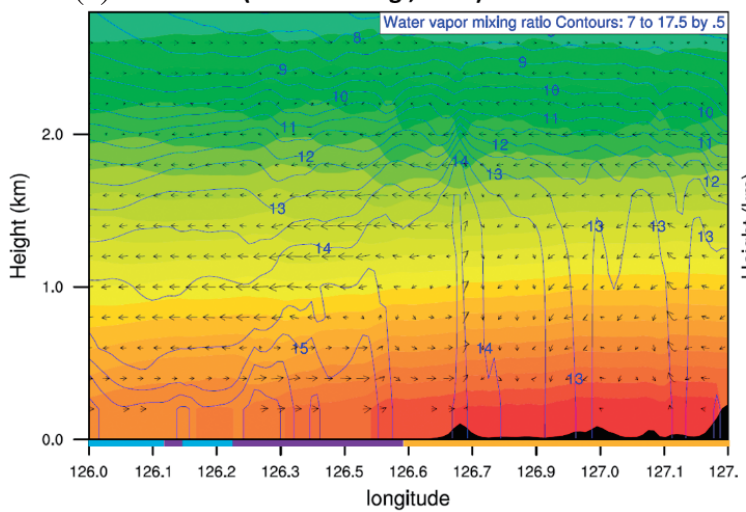

(b) HIGH (04 LST 20 Aug., 2016)

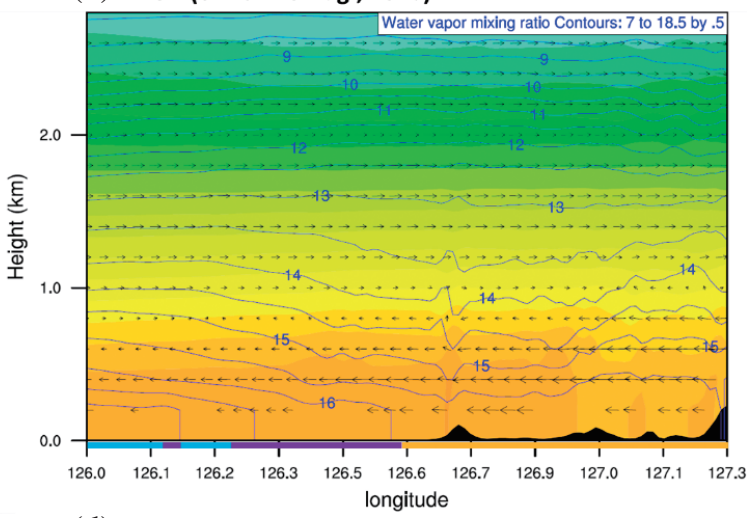

(d) HIGH (16 LST 20 Aug., 2016)

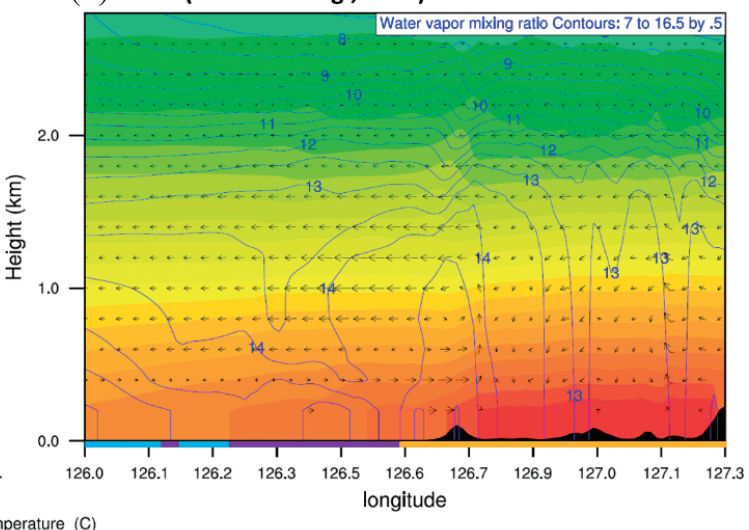

Temperature (C)

$\begin{array}{lllllllllll}10 & 12 & 14 & 16 & 18 & 20 & 22 & 24 & 26 & 28 & 30\end{array}$

Fig. 7. The vertical cross-section plot of $\mathrm{u}$ and $\mathrm{w}$ vectors, $\mathrm{Q}$ (blue contour line), and $\mathrm{T}$ (shading color) along the line shown in Fig. $1 \mathrm{~b}$ (purple dashed line) for (a) (c) WETLAND and (b) (d) HIGH. The color bar on the $x$-axis represents land cover type (sky blue: sea, purple: intertidal zone, and yellow: land). 
The horizontal and vertical impacts of tidal effect on coastal meteorology were more pronounced at high tide than at low tide. Overall, the effect of high tide was more significant during the summer period than during the winter period, and it had a particularly large influence on $\mathrm{T}$ and $\mathrm{Q}$. A detailed analysis of the meteorological variables showed that $\mathrm{T}$ in the coastal areas and intertidal zone, decreased (up to $3.4^{\circ} \mathrm{C}$ ) in the afternoon during summer and increased (up to $3.2^{\circ} \mathrm{C}$ ) in the morning during winter. Q significantly increased (up to $2.0 \mathrm{~g} \mathrm{~kg}^{-1}$ in the morning and up to $2.9 \mathrm{~g} \mathrm{~kg}^{-1}$ in the afternoon) during the summer period, and the effects were seen as far as $30 \mathrm{~km}$ inland from the shoreline due to a strengthened sea breeze. Moreover, the surface WS in some areas of the inland increased (up to $1.3 \mathrm{~m} \mathrm{~s}^{-1}$ ) in the afternoon of summer, and that in the nearby sea and intertidal zone, increased (up to $2.7 \mathrm{~m} \mathrm{~s}^{-1}$ ) in the morning of winter. In particular, during summer, the westerly WS in the lower atmosphere (within $0.4 \mathrm{~m}$ ) significantly increased (up to $5.4 \mathrm{~m} \mathrm{~s}^{-1}$ ) in the adjacent inland area and intertidal zone, due to a greater land-sea contrast induced by high tide; therefore, the easterly WS increased (up to $3.2 \mathrm{~m} \mathrm{~s}^{-1}$ ) at approximately the heights (approximately $1 \mathrm{~km}$ ) of the return current of the sea breeze. These horizontal and vertical variations in sea breeze circulation led to differences in coastal meteorology both in the Seoul metropolitan area (within $30 \mathrm{~km}$ inland from the shoreline) and intertidal zone, and within the PBL (approximately $1.5 \mathrm{~km}$ altitude).

This study demonstrated that land cover changes due to the tidal effect have a significant influence on the horizontal and vertical meteorological changes in the intertidal zone as well as inland and offshore. This study has limitations in not simulating time-varying land cover and SST in intertidal zones. If these limitations are overcome in the future, the meteorological impacts of tidal effects in intertidal zones will be more realistically simulated in meteorological models. In addition, this study is expected to be the basis for future meteorological studies on the intertidal zone.

Acknowledgements This research was supported by Basic Science Research Program through the National Research Foundation of Korea (NRF) funded by the Ministry of Education (2017R1D1A1B03034592) and (2017R1D1A1B03033493).

\section{REFERENCES}

Ahrens, C. D., 2009: Meteorology Today: An Introduction to Weather, Climate, and the Environment, 9th Editon, Brooks/Cole, Cengage Learning, Belmont, 599 pp.

Han, Z. and F. Peng, 2012: Soil moisture quantitative study of the Nanhui tidal flat in the Yangtze river estuary by using ENVISAT ASAR data. 2012 International Conference on Systems and Informatics (ICSAI), Yantai, China, IEEE, doi: 10.1109/ICSAI.2012.6223485. [Link]
Harrison, S. J. and A. P. Phizacklea, 1985: Seasonal changes in heat flux and heat storage forth estuary, Scotland in the intertidal mudflats of the forth estuary, Scotland. $J$. Climatol., 5, 473-485, doi: 10.1002/joc.3370050502. [Link]

Heo, K.-Y., S. Park, K.-J. Ha, and J.-S. Shim, 2014: Algorithm for sea fog monitoring with the use of information technologies. Meteorol. Appl., 21, 350-359, doi: 10.1002/met.1344. [Link]

Hong, S.-K., C.-H. Koh, R. R. Harris, J.-E. Kim, J.-S. Lee, and B.-S. Ihm, 2010: Land use in Korean tidal wetlands: Impacts and management strategies. Environ. Manage., 45, 1014-1026, doi: 10.1007/s00267-0060164-3. [Link]

Kim, T.-W., Y.-K. Cho, and E. P. Dever, 2007: An evaluation of the thermal properties and albedo of a macrotidal flat. J. Geophys. Res., 112, C12009, doi: 10.1029/2006JC004015. [Link]

Lathlean, J. A., D. J. Ayre, and T. E. Minchinton, 2011: Rocky intertidal temperature variability along the southeast coast of Australia: Comparing data from in situ loggers, satellite-derived SST and terrestrial weather stations. Mar. Ecol. Prog. Ser., 439, 83-95, doi: 10.3354/meps09317. [Link]

Lee, Y.-H., K.-D. Ahn, and Y. H. Lee, 2016: Parametrization of the tidal effect for use in the noah land-surface model: Development and validation. Bound.-Layer Meteor., 161, 561-574, doi: 10.1007/s10546-016-0178-1. [Link]

Onken, R., U. Callies, B. Vaessen, and R. Riethmuller, 2007: Indirect determination of the heat budget of tidal flats. Cont. Shelf Res., 27, 1656-1676, doi: 10.1016/j. csr.2007.01.029. [Link]

Park, S.-E., W. M. Moon, and D. Kim, 2009: Estimation of surface roughness parameter in intertidal mudflat using airborne polarimetric SAR data. IEEE Trans. Geosci. Remote Sensing, 47, 1022-1031, doi: 10.1109/ TGRS.2008.2008908. [Link]

Piccolo, M. C., G. M. E. Perillo, and G. R. Daborn, 1993: Soil temperature variations on a tidal flat in Minas Basin, Bay of Fundy, Canada. Estuar. Coast. Shelf Sci., 36, 345-357, doi: 10.1006/ecss.1993.1021. [Link]

Ramsar Convention Secretariat, 2013: The Ramsar Convention Manual: A Guide to the Convention on Wetlands (Ramsar, Iran, 1971), 6th Edition, Ramsar Convention Secretariat, Gland, Switzerland, 109 pp.

Raubenheimer, B., D. K. Ralston, S. Elgar, D. Giffen, and R. P. Signell, 2013: Observations and predictions of summertime winds on the Skagit tidal flats, Washington. Cont. Shelf Res., 60, S13-S21, doi: 10.1016/j. csr.2012.02.001. [Link]

Ryu, J., S. Hong, W. K. Chang, and J. S. Khim, 2016: Performance evaluation and validation of ecological indices toward site-specific application for varying benthic conditions in Korean coasts. Sci. Total Environ., 
541, 1161-1171, doi: 10.1016/j.scitotenv.2015.10.016. [Link]

Scott, D. B., J. Frail-Gauthier, and P. J. Mudie, 2014: Coastal Wetlands of the World: Geology, Ecology, Distribution and Applications, Cambridge University Press, doi: 10.1017/CBO9781107296916. [Link]

Skamarock, W. C., J. B. Klemp, J. Dudhia, D. O. Gill, D. M. Barker, M. G. Duda, X. Y. Huang, W. Wang and
J. G. Powers, 2008: A description of the advanced research WRF version 3. NCAR Technical Note, NCAR/ TN-475+STR, National Center for Atmospheric Research, Boulder, Colorado, USA, 125 pp, doi: 10.5065/ D68S4MVH. [Link]

Tokinaga, H. and S.-P. Xie, 2009: Ocean tidal cooling effect on summer sea fog over the Okhotsk Sea. J. Geophys. Res., 114, D14102, doi: 10.1029/2008JD011477. [Link]

\section{APPENDIX}

(a) HIGH (Morning)

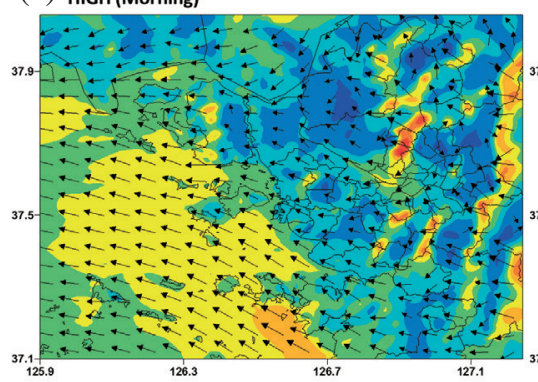

(c) HIGH (Afternoon)

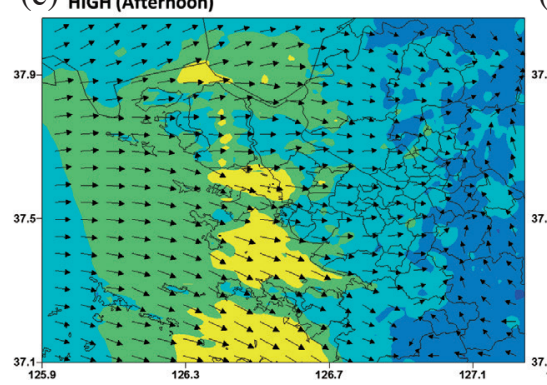

(b) WETLAND (Morning)

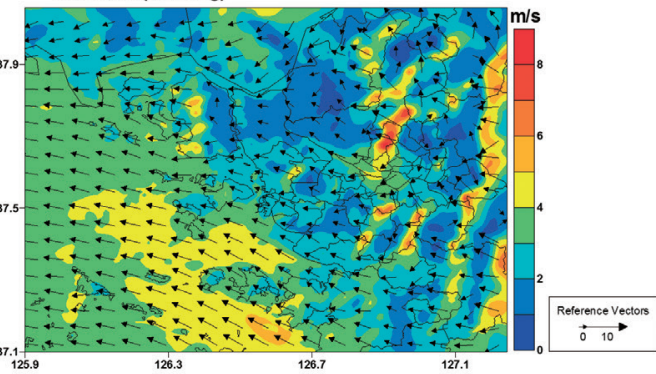

(d) WETLAND (Afternoon)

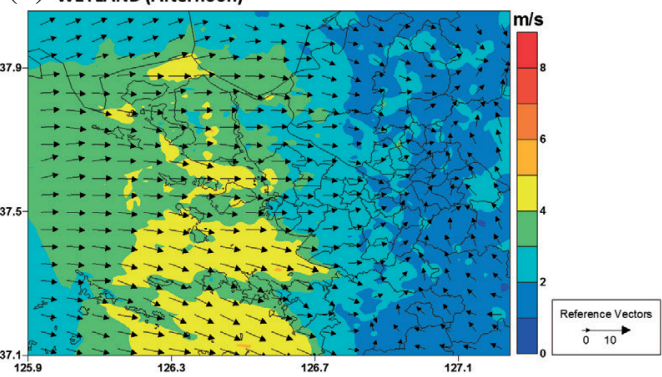

Fig. A1. Spatial distribution of mean surface winds for the (a) (c) HIGH case and (b) (d) WETLAND case during the morning (a) (b) and afternoon (c) (d) of summer.

(a) HIGH (Morning)

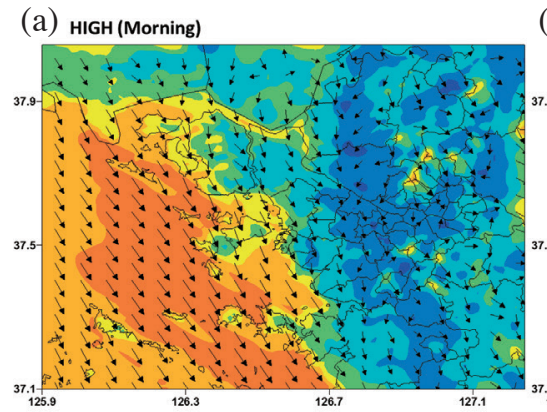

(b) WETLAND (Morning)
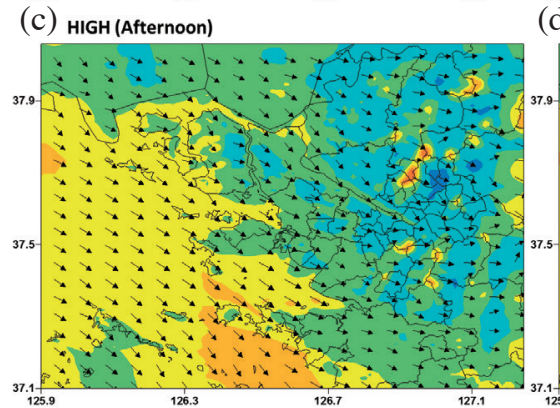

(d) WETLAND (Afternoon)
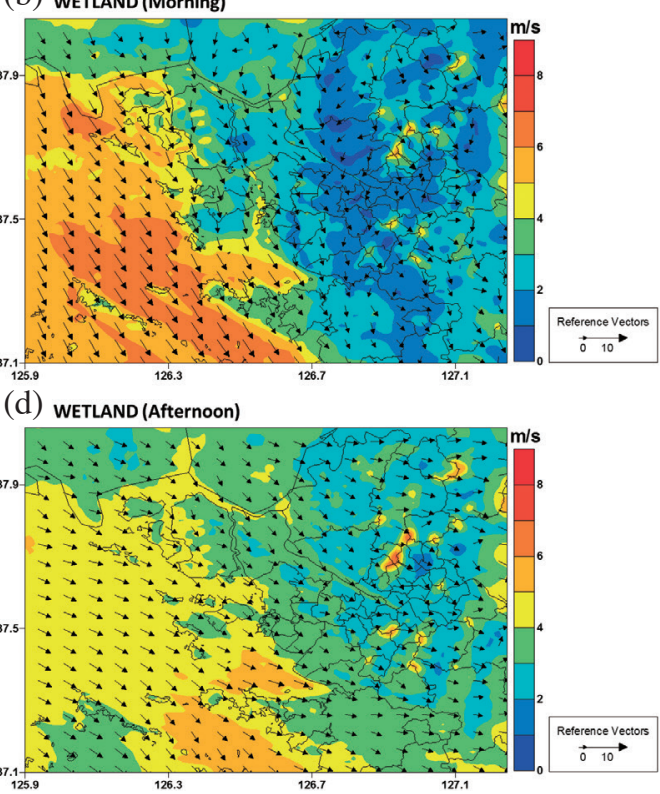

Fig. A2. Same as Fig. A1 but for winter. 